\title{
The Climate Crisis as a Product of Globalization
}

\author{
Magdalena Raftowicz* \\ Wrocław University of Environmental and Life Sciences, Institute of Economic Sciences, pl. \\ Grunwaldzki 24a, 50-363 Wrocław, Poland
}

\begin{abstract}
.
Research background: the processes of globalization have led to an increasing interdependence and integration of states, societies, economies, and cultures, which result in the emergence of one world that produces the same products. However, little do people realize that global products have also a negative influence on the global economy. A clear example is the climate crisis, which can be treated as a product of globalization.

Purpose of the article: therefore, the main aim of the paper is an attempt to answer the question: what is the impact of unlimited globalization processes on the climate crisis. The main hypothesis of the research is that the adoption of a degrowth model can effectively stop the negative effects of the climate crisis, which may lead to a global economic recession in the future. However, this will require inter-state simultaneous cooperation, because no single country can solve the climate problem separately.

Methods: to confirm such a hypothesis, and to formulate the main findings, the method of critical analysis of the literature on climate and economic matters was used.

Findings \& Value added: the main added value of the paper is the synthetic forecast of the economic effects caused by global climate change. It may enrich the discussion about the effects of climate change through dissemination and acceptance of scientific knowledge. The negation of this knowledge, still frequently observed in public debates, may delay the implementation of urgent and necessary solutions.
\end{abstract}

Keywords: global climate changes; globalization; degrowth

JEL Classification: $F 62 ; O 44 ; P 56$

\section{Introduction}

The beginning of the 21 st century introduced a new chapter into the global economy - the climate crisis. This process is a consequence of the rapid economic growth already initiated by the industrial revolution in the 18th century. On the one hand, this revolution became a

\footnotetext{
*Corresponding author: magdalena.raftowicz@upwr.edu.pl
} 
driving force for the development of industry, agriculture, transport, trade and urban planning, but on the other hand, it contributed to overloading the natural environmental systems of our planet. These processes have particularly intensified since the end of the 20th century, which dates back to the period of rapid globalization [1], when individual countries were becoming more and more open to forces influencing them from the outside of their borders, thus leading to interdependence and integration at the level of states and societies, cultures, as well as economies.

The main aim of the paper is an attempt to answer the question: what is the impact of unlimited globalization processes on the climate crisis and what actions should be taken to stop this crisis. The research is based on critical studies of the literature on climate change analysed through the prism of economic issues.

\section{Climate crisis}

Nowadays, we can distinguish nine barriers to the development of our planet (the first two of which have long been exceeded). These include, according to the scale of the problem [2]:

1. Climate change (climate warming)

2. Loss of biodiversity,

3. Excessive level of agricultural land use,

4. Water consumption,

5. Acidification of the oceans,

6. Exceeding the levels of phosphorus use,

7. Depletion of the ozone layer,

8. Exceeding nitrogen use levels,

9. Aerosol concentration and chemical contamination.

Among these factors, the greatest threat is the climate change, which is adversely affected by the remaining eight elements whose indicators keep constantly increasing. To this set of climate change causes, the European Commission [3] also adds burning of fossil fuels, cutting down rainforests and raising livestock. The scale of the global waste of resources (as well as their constantly deepening deficit), both renewable and non-renewable due to excessive consumption, causes concern. It is predicted that by 2020 in the new EU countries the consumption of resources will increase by over $60 \%$, to the level of almost 1.7 billion tons.

Unfortunately, the current global policy to combat climate change has turned out to be ineffective. A clear example is the increase in global greenhouse gas emissions by $30-40 \%$ in 1990-2009 - despite the assumed decrease [4]. In the longer term, new investments in the extraction of fossil fuels of USD 22.87 trillion are planned by 2035, with a simultaneous investment in renewable, hydro and nuclear energy of only USD 7.32 trillion. By confronting this data with the calculations of M.Z. Jacobson and M.A. Delucchi [5] from 2009 , who showed that it would be possible (both economically and technically) to convert the world to renewable energy in 2030 at the cost of USD 100 trillion, it may undermine the further sense of the research on the sustainable development concept, which implies care for future generations, in a way as it is done these days. All the more reason, the estimated value of the oil reserves is only USD 50 trillion.

Established in 2010, the Green Climate Fund, which was intended to raise USD 100 billion for third world countries for adaptation to climate change, had collected less than USD 1 billion by 2016 and a total of just USD 5.3 billion four years later [6]. This means that the most developed countries in the world are quite reluctant to allocate funds to common environmental goals. Moreover, scientists have calculated that the signing of the Intended Nationally Determined Contributions on a voluntary commitment to reducing 
greenhouse gas emissions and adapting to climate change by the signatories of the Paris Agreement does not solve the problem, as there still is a $90 \%$ probability of an increase in global temperature above $2^{\circ} \mathrm{C}$, until 2100 [7]. In the face of such threats, the question arises whether there is a real possibility of reversing or eliminating these negative statistics? The answer to this question lies behind the concept of globalization.

\section{Globalization}

In the literature on the subject, there are many definitions of globalization that relate to both aspects of trade and financial integration [8]. In general, it can be assumed that globalization is a socio-economic process that represents economic phenomena in the worldwide. Apart from the unquestionable enormity of positive benefits resulting from globalization (e.g. increased exports, increased employment, access to technologies, products and services) [9], the processes of globalization also have their negative features. The most dangerous is the fact that, unlike other economic and organizational processes, globalization has now eluded the possibility of its top-down control.

Focusing in this article only on the aspect of nature protection in the context of climate change, it can be concluded that free market globalization deprives local and regional communities of control over their environment, incapacitating them against the powerful forces of international capital. Transnational corporations externalize the costs of producing cheap goods, reaping huge profits, and transferring most of the harmful side effects of production to local communities (including employees) and the environment, which results, for example, in the problem of smog, which occurs only locally. Globalization also facilitates offshoring, i.e. the transfer of production abroad, thus lowering the costs of transport, communication, and customs [10]. Thus, globalization favours the creation of the dirty industry migration effect (pollution heaven hypothesis) from developed countries to low-income countries, where the costs of environmental pollution are significantly lower. This means that globalization should be considered from the perspective of abuses of the system and acknowledged that climate change is a specific product of globalization. This is due to the fact that today we are dealing with the process of unlimited globalization, which further stimulates unlimited economic growth and thus accelerates climate change. The question is, can globalization be controlled to counteract climate change?

Many scientists (and fairly) believe that today we are dealing with a situation in which markets strive for globalization, while the institutions needed to support them remain mostly national [11]. Referring to Rodrik's paradox of globalization, which suggests that in the world of economics, the issues of globalization, democracy and sovereignty cannot be combined, we can conclude that concern for environmental protection also excludes the neo-liberal cult of economic growth and thus globalization. A clear example of this is the introduction of an unprecedented tool- permits for the greenhouse gas emissions trading, which, however, did not revolutionize the status quo of climate policy. Therefore, it can be argued that in the era of financialization (i.e. the domination of the financial sector in general economic activity [12]), the issue of environmental pollution becomes a bargaining object, and the right to poison - a lucrative business.

In the wake of the lack of real changes, more and more researchers assess climate policy as ineffective, devoid of effective tools or institutional solutions. This thesis is confirmed by the fact that, paradoxically, the most developed countries in the world, which derive the greatest benefits from the process of uncontrolled globalization, do not always fully accept, and thus implement policies to counteract climate change. An example is the United States - the biggest opponent of the Kyoto Protocol, which concerned the reduction of greenhouse gases, or Canada, which "left Kyoto" in 2011. A similar situation took place during the Paris conference, when the United States withdrew from the agreement in July 2017. It has 
been calculated that the United States, whose economy is based on high gas emissions, would suffer only slightly in the initial stage of global warming compared to the enormous costs that the US would have to bear to fight the climate crisis, which shows how shortsighted the political vision of the rulers is.

In the Era of Consequences report by the US Center for Strategic and International Studies (CSIS), experts warn that climate change could bring an end to globalization [13]. So what should be done? The solution to this problem can be seen in the implementation of the degrowth model, combined with effective supra-state regulations.

\section{Methodology and results - The concept of economic degrowth}

The model of degrowth is a relatively new, niche, interdisciplinary paradigm in economic theory, which has been developing intensively and gaining more and more supporters, as evidenced by the increasing number of publications devoted to this issue [14]. It is an alternative to the modern neoliberal paradigm that emphasizes the cult of profit and growth. However, it should be realized that the rush to growth, identified with the macroeconomic levers of the modern economy, cannot last indefinitely due to the limited supply of natural resources and market failures. Hence, economists were looking for a model that would revolutionize the blind and short-sighted approach to economic growth.

Generally, it can be assumed that the concept of degrowth is based on three assumptions $[15,16]$ :

- a significant part of the human ecosystem (planet) resources is inherently limited,

- infinite growth (demographic, economic) in a finite world is impossible,

- GDP is not a good indicator of economic growth.

The common feature of this concept is that they equate 'degrowth' with 'deconstruction of reality' or 'detoxification of the environment'. The novelty of degrowth is that it is a proposal to open up a new space for innovation and imaginative creativity in the world, it is the perspective of exploring new opportunities by setting alternative economic goals and recognizing other boundaries (ecological and social) [17].

The concept of degrowth differs from other economic categories as it is not a category of negative or zero growth, achieved only thanks to restrictions, sacrifices or limiting production. Growth remains important as it provides long-term development. Thus, it can be concluded that a degrowth means growth, only qualitative growth: i.e. 'clean' and green, in other words, growth not measured by GDP indicators.

A real example of what could be described as controllable growth was the $2019 \mathrm{New}$ Zealand budget, which focuses on five priority areas: helping the transition to a sustainable and low-carbon economy, reducing child poverty, supporting indigenous peoples, welfare in the digital age, and concern for the mental health of its inhabitants [18].

The uncontrolled growth phenomenon could be observed during the COVID-19 pandemic, when the freezing of the global economy and the introduction of the principles of social isolation had a positive impact on the state of the natural environment. For example, on April 7th 2020, the lowest level of global carbon dioxide emissions since 2006 was recorded. The average daily decrease in global carbon dioxide emissions decreased by $17 \%$ (from approx. 100 million tonnes to 83 million tonnes of $\mathrm{CO}_{2}$ emissions per day) compared to the daily average for $2019.43 \%$ of the reduction in $\mathrm{CO}_{2}$ emissions was due to the reduction of surface transport, another $43 \%$ to the decline in industrial activity and electricity production, and $10 \%$ to the reduction in air transport. Scientists have calculated that the impact of the coronavirus-related restrictions will lead to an average decrease in carbon dioxide emissions of $4-7 \%$ in 2020 compared to 2019. [19] However, as the economy completely thaws, it can be assumed that the situation will return to normal. 
Therefore, such uncontrolled, unintended phenomena will not have an impact on the fate of the world in the long term.

M. Bonaiuti [20] sees a solution to the problem in the transformation of 'uncontrolled growth' into a 'controlled process' that would also curb globalization. How can this be done? Through supranational regulations. As rightly noted by J. Stiglitz [21], the existing system of global governance without a global government cannot function satisfactorily and properly in times when there is a great need for global institutions, and trust in contemporary organizations is very small. Moreover, the freer the markets, the greater the burden on regulators [22,23]. Economic entities, especially transnational ones, are not interested in voluntarily incurring additional costs to counteract climate change, and all calls for moderation and sacrifice in a globalized free market economy are irrelevant. It can therefore be concluded that with the further development of globalization, states will be forced to take greater care of environmental protection. However, this will require simultaneous cooperation between countries, as no country can solve the climate problem on its own.

\section{Discussion and conclusion}

The presented analysis showed that we are currently dealing with an uncontrolled process of globalization, which intensifies the cult of economic growth and, consequently, leads to negative climate changes. Transforming the process of unlimited globalization into controlled globalization can counteract climate change.

The author postulates that the world economy should be reformed in such a way that the end of economic growth (to which we are inevitably approaching) would not mean the end of prosperity.

Adopting the model of degrowth may effectively stop the negative effects of the climate crisis, which may lead to a global economic recession in the future. However, this will require international political cooperation due to the fact that it is impossible to solve the climate problem all alone, as it is now a global product, the effects of which are experienced throughout the world.

\section{References}

1. Strum, D. (2020). The Origins of Globalization: World Trade and the Making of the Global Economy. Journal of Interdisciplinary History, 50 )3), 438-440.

2. Rockström, J., Steffen, W., Noone, K., Persson, Å., Chapin, F.S., Lambin, E., Lenton, T.M., Scheffer, M., Folke, C., Schellnhuber, H., Nykvist, B., De Wit, C.A., Hughes, T., van der Leeuw, S., Rodhe, H., Sörlin, S., Snyder, P.K., Costanza, R., Svedin, U., Falkenmark, M., Karlberg, L., Corell, R.W., Fabry, V.J., Hansen, J., Walker, B., Liverman, D., Richardson, K., Crutzen, P., Foley J. (2009). Planetary boundaries: exploring the safe operating space for humanity. Ecology and Society, 14(2), Article Number 32.

3. European Commission. Retrieved from: https://ec.europa.eu/clima/change/causes_en.

4. Lewis, J. (2013). Beyond Consumer Capitalism, Media and the Limits to Imagination, Cambridge, UK: Polity Press.

5. Jacobson, M.Z., Delucchi, M.A. (2009). A Plan to Power 100 Percent of the Planet with Renewables. Scientific American, 11.

6. Green Climate Fund. (2020). Retrieved from: https://www.greenclimate.fund/ 
7. Bińczyk, E. (2018). Epoka człowieka. Retoryka i marazm antropocenu, [The age of man. Rhetoric and apathy of the Anthropocene]. Warszawa: PWN.

8. Ma, L., Ruzic, D. (2020). Globalization and top income shares. Journal of International Economics, 125, Article Number 103312.

9. Kwon, H., Kim, K.M. (2020). Varieties of globalisation and national economy: Korea's experience from a comparative perspective. Journal of International Relations and Development, 23(3), 728-754.

10. Liu, R., Trefler, D. (2019). A sorted tale of globalization: White collar jobs and the rise of service offshoring. Journal of International Economics, 118, 105-122.

11. Rodrik, D. (2019). Globalization's Wrong Turn And How It Hurt America. Foreign Affairs, 98(4), 26-33.

12. Matysiak, A., Raftowicz M. (2019). Polimorfizm systemu gospodarczego [Polymorphism of economic system]. Studia Ekonomiczne. Zeszyty Naukowe Uniwersytetu Ekonomicznego w Katowicach, 378, 7-18.

13. Center for Strategic and International Studies. (2007). The Age of Consequences, Retrieved from: https://www.csis.org/programs/about-us.

14. Khmara, Y., Kronenberg, J. (2020). Degrowth in the context of sustainability transitions: In search of a common ground. Journal of Cleaner Production, 267, Article Number 122072.

15. Koch, M., Buch-Hansen, H. (2020). In search of a political economy of the postgrowth era, Globalizations, Early Access.

16. Mair, S., Druckman, A., Jackson, Tim. (2020). A tale of two utopias: Work in a postgrowth world. Ecological Economics, 173, Article Number 106653.

17. Matysiak, A., Raftowicz-Filipkiewicz, M. (2017), Wpływ procesów endogenicznych na rozwój zrównoważony [The influence of the endogenous processes on the sustainable development]. Studia Ekonomiczne. Zeszyty Naukowe Uniwersytetu Ekonomicznego w Katowicach, 311, 37-47.

18. World Economic Forum, 2019, New Zealand has unveiled its first 'well-being' budget, Retrieved from: https://www.weforum.org/agenda/2019/05/new-zealand-is-publishingits-first-well-being-budget/.

19. World Economic Forum, 2020, Daily global CO2 emissions 'cut to 2006 levels' during height of coronavirus crisis, Retrieved from: https://www.weforum.org/agenda/2020/05/enviroment-coronavirus-covid19-pandemicemissions-co2-pollution.

20. Bonaiuti M. (2018). Are we entering the age of involuntary degrowth? Promethean technologies and declining returns of innovation. Journal of Cleaner Production, 197(2), 1800-1809.

21. Stiglitz, J.E. (2003). Globalization and the economic role of the state in the new millennium. Industrial and Corporate Change, 12(1), 2-26.

22. Rodrik, D. (2009). One Economics, Many Recipes: Globalization, Institutions, and Economic Growth. New Jersey: Princeton University Press.

23. Stiglitz, J. E. (2019). Addressing climate change through price and non-price interventions. European Economic Review, 119, 594-612. 